\title{
EFFECT OF PUERPERIUM INTENSIVE CARE ON THE WILLINGNESS TO PROVIDE EXCLUSIVE BREASTFEEDING
}

\author{
Yunik Windarti, Uke Maharani Dewi \\ Faculty of Nursing and Midwifery, Universitas Nahdlatul Ulama, Surabaya
}

\begin{abstract}
Background: The puerperium period refers to the time after delivery when maternal physiological changes related to pregnancy return to the nonpregnant state. In puerperal period the nursing staff has an important educational role to the care that the woman in puerperium must have with herself and with the baby. There are factors involved in the difficulty of implementing infant care, particurlarly exclusive breastfeeding (EBF) and early interruption of breastfeeding. This study aimed to determine the effect of puerperium intensive care on the willingness to provide EBF.

Subjects and Method: This was a randomized controlled trial conducted in Wonokromo, Surabaya, East Java. A sample of 80 postpartum mothers was selected for this study, and randomly allocated into 2 groups: 40 mothers in the puerperium intensive care group and 40 mothers in the control group. The dependent variable was the willingness to provide EBF. The independent variable (intervention) was puerperium intensive care. Willingness to provide EBF was measured by a questionnaire. Percent difference in the willingness to provide the EBF between the two groups was tested by chi-square, with risk ratio (RR) as the measure of effect.

Results: Before the intervention, the two groups were comparable in term of percent of mothers willing to provide EBF, indicating the success of randomization. After the intervention, percent of mothers willing to provide EBF in the intervention group (57.5\%) was higher than the control group (45\%) with $\mathrm{RR}=1.28$, and it was statistically significant ( $p=0.019)$. $R R=1.28$ means that postpartum mothers who received the puerperium intensive care were 1.28 times as likely to provide EBF than those who did not receive the intervention.
\end{abstract}

Conclusion: Puerperium intensive care is effective to enhance the willingness to provide $\mathrm{EBF}$ among postpartum mothers.

Keywords: puerperium intensive care, breastfeeding

Correspondence:

Yunik Windarti. Faculty of Nursing and Midwifery, Universitas Nahdlatul Ulama, Surabaya, East Java. Email: yunikwinda@unusa.ac.id. Mobile: o8133033090.

The $6^{\text {th }}$ International Conference on Public Health

Best Western Premier Hotel, Solo, Indonesia, October 23-24, 2019 | 235

https://doi.org/10.26911/the6thicph.03.93 